\title{
Settlement behaviour of ascidian larvae: preliminary evidence for inhibition by sponge allelochemicals
}

\author{
Andrew R. Davis ${ }^{1, *}$, Alan J. Butler ${ }^{1}$, Ian van Altena ${ }^{2, * *}$ \\ ${ }^{1}$ Department of Zoology, University of Adelaide, GPO Box 498, Adelaide, South Australia 5001, Australia \\ ${ }^{2}$ Department of Organic Chemistry, University of Adelaide, GPO Box 498, Adelaide, South Australia 5001, Australia
}

\begin{abstract}
Recruitment in many marine invertebrates is inherently variable; the behaviour of larvae at settlement may be an important contributor to this variation. Yet there are few in situ observations of settlement behaviour of marine invertebrate larvae. Direct observations in the field showed that $63 \%(\mathrm{n}=$ 89) in larvae of the colonial ascidian Podoclavella moluccensis Sluiter settled on their first contact with the substratum, while a small percentage made 10 or more contacts prior to settlement. Two species of subtidal sponge, Mycale sp. and Crella incrustans, were consistently avoided by these settling larvae. Mycale sp. was often contacted repeatedly, but invariably rejected. In contrast, even contacts with $C$. incrustans were rare, relative to the space that this sponge occupied. We investigated the role of sponge allelochemicals, at natural concentrations, in inhibiting settlement of these larvae. Settlement of larvae onto substrata impregnated with an ether-soluble extract of Mycale sp. was significantly inhibited, relative to controls. Several fractions of this extract were equally inhibitory to settling larvae. Butanol and ether extracts of $C$. incrustans were also inhibitory and the repellent activity was in the more polar lipophilic fractions. The least polar fraction was attractive to larvae. Extracts appeared to be non-toxic to the larvae and we failed to detect any antibacterial activity. We conclude that settlement of these ascidian larvae may be inhibited by natural products released from or at the surface of these sponges.
\end{abstract}

\section{INTRODUCTION}

Variation in the initial settlement of marine invertebrates may have a significant influence on distribution and abundance of adults, and also on community structure (Connell 1985, Gaines \& Roughgarden 1985, Davis 1988). The behaviour of larvae can, in part, determine these patterns of recruitment. For example, some larvae seek the protection of pits and crevices (Connell 1961, Keough \& Downes 1982) while others avoid settling on or near organisms that may lower their survival (Grosberg 1981, Davis 1987). The cues by which larvae distinguish between substrata are poorly understood and are likely to be complex (Burke 1983).

Despite the perceived importance of settlement to community structure and dynamics, direct observations of larval settlement in the field are few. Davis (1987) observed the initial response of settling larvae of the

\footnotetext{
- Present address: Department of Biology, University of Wollongong, PO Box 1144, Wollongong, NSW 2500, Australia

- Order of authorship randomly determined
}

colonial ascidian Podoclavella moluccensis Sluiter (Clavelinidae: Aplousobranchia) on their first encounter with 5 types of substratum: bare space (wood) and 4 species of sponge. These observations indicated that larvae were highly selective and showed a clear preference for bare space, rarely settling on the unfouled matrix of sponges. One sponge, Mycale sp., was consistently rejected. Others, including Crella incrustans [previously called Tedania sp. A in Davis (1987)], were selected less often than expected from their relative abundances.

In this paper we present additional field observations on settlement behaviour of Podoclavella moluccensis larvae. We then test the hypothesis that allelochemicals contribute to this behaviour by examining the responses of larvae to crude and fractionated extracts of 2 species of sponge that were consistently avoided.

\section{MATERIALS AND METHODS}

Field observations and settlement trials were conducted beneath Edithburgh pier, South Australia. This 
site and its fauna are described in Kay \& Keough (1981), Kay \& Butler (1983) and Davis (1987).

Field observations of ascidian settlement. Podoclavella molluccensis larvae were released from adults for ca $6 \mathrm{wk}$ of each year, beginning in late spring. Traps were fitted over reproductive colonies and the larvae released were followed directly using SCUBA (Davis 1987, Davis \& Butler 1989). Individual larvae were followed until they either settled or were lost. The substrata touched by each larva and the number of contacts were recorded. The time a larva had spent in a trap did not appear to alter its behaviour (Davis \& Butler 1989). The area of substrata available for contact was estimated with the haphazard placement of $13 \times$ $17.5 \mathrm{~cm}$ quadrats $\left(227.5 \mathrm{~cm}^{2}\right)$ onto the pier pilings. The substratum that dominated each of the 150 quadrats was recorded.

The frequency of observed contacts was then compared to that expected, based on the area of each substratum available for settlement. Low expected frequencies were apparent with some of the substrata. Sokal \& Rohlf (1981) maintain that it is appropriate to use a $G$-test to compare observed and expected frequencies if there are 5 or more groups with expected frequencies of 3 or more. Some substrata were pooled to meet this condition.

Preparation of extracts. We investigated extracts of 2 sponges, Mycale sp. (SP20 code of voucher specimens held at the University of Adelaide, South Australia, and deposited in the South Australian Museum) and Crella incrustans (Northern Territory Museum numbers Z3581, Z3582, Z3583).

Mycale sp. was collected from beneath the Edithburgh pier in May 1988 and stored frozen at $-14{ }^{\circ} \mathrm{C}$ until extraction commenced in October 1988. The frozen sponge was extracted by blending it with acetone $(4 \times 11)$ in a Waring Blender. All solvents were redistilled. The acetone-sponge mixture was filtered through diatomaceous earth (Celite) after each extraction. The acetone was removed under vacuum to provide a thick aqueous mixture. The volume was made up to $600 \mathrm{ml}$ with water and the mixture extracted with diethyl ether $(5 \times 500 \mathrm{ml})$. The ether extract was dried with anhydrous $\mathrm{MgSO}_{4}$ and the ether removed under vacuum to give the crude lipophilic extract $(5.4 \mathrm{~g}$ $2.6 \%$, based on the weight of the dried sponge residue remaining).

A portion of the extract $(1.2 \mathrm{~g})$ was chromatographed on Sephadex LH-20 (Pharmacia) using methanol: chloroform $1: 1$ as the eluent, to give 4 successive fractions: $2-99 \mathrm{~A}(80 \mathrm{mg}), 2-99 \mathrm{~B}(220 \mathrm{mg}), 2-99 \mathrm{C}(670 \mathrm{mg})$, 2-99D (5 mg).

Crella incrustans was collected under the Edithburgh pier in October 1989 and kept frozen until November 1989, when extraction commenced. The sponge was extracted as above using acetone $(4 \times 51)$ and the aqueous residue extracted with ether $(4 \times 1 \mathrm{l})$ followed by $n$-butanol $(3 \times 800 \mathrm{ml})$ to give, after drying and removal of solvents, crude extracts $2-181 \mathrm{~A}(16 \mathrm{~g})$ and $2-181 \mathrm{~B}(3.5 \mathrm{~g})$ respectively. The yields based on the weight of dried sponge residue were 3 and $0.6 \%$ respectively.

A portion of 2-181A (ether extract, $6.1 \mathrm{~g}$ ) was submitted to rapid vacuum chromatography on silica-gel (Coll \& Bowden 1986) to give 7 fractions [2-183A $(0.54 \mathrm{~g})$ to 2-183G]. 2-183A was the least polar fraction and was eluted with mixtures ranging from 0 to $40 \%$ dichloromethane and light petroleum.

A second portion of $2-181 \mathrm{~A}(1.7 \mathrm{~g})$ was chromatographed on Sephadex LH-20 using chloroform:light petroleum:ethanol $(10: 10: 1)$ as the eluent. Seven fractions were collected: $2-181 \mathrm{~J}, \mathrm{~K}, \mathrm{~L}(680 \mathrm{mg})$; $\mathrm{M}(300 \mathrm{mg})$; $\mathrm{N}(43 \mathrm{mg}) ; \mathrm{P}(51 \mathrm{mg}) ; \mathrm{Q}(41 \mathrm{mg}) .2-181 \mathrm{Q}$ was the most polar fraction.

To estimate a 'natural' concentration of crude extract for use in tests, we assumed that all of the active compound(s) is concentrated at the surface and made an estimate of the surface area of the extracted sponge. This was more straightforward for Mycale sp. than for Crella incrustans because the former has a thin encrusting growth form, whereas $C$. incrustans is more mound-form and lobed.

In the case of Crella incrustans, each chromatographic fraction was tested at a concentration corresponding to its percentage recovery from the column. Thus any active compounds in the chromatographic fractions of $C$. incrustans would be present in the tests at less than or equal to the concentration present in the original crude ether extract (2-181A). Concentrations (in $\mu \mathrm{g} \mathrm{cm}^{-2}$ ) used in each test were as follows. Mycale sp.: (1) Total ether extract, 1500; (2) 2-99A, 350; (3) 2 99B, 970; (4) 2-99C, 1460. Crella incrustans: (5) 2-181A, $500 ;(6) 2-181 \mathrm{~B}, 123 ;$ (7) $2-181 \mathrm{~L}, 200 ;$ (8) 2-181M, 87; (9) $2-181 \mathrm{P}, \quad 14 ;$ (10) 2-181Q, 12; (11) 2-183A, 44; (12) Cholesterol, 500.

The Mycale sp. extracts were tested in the field on 3 to 5 November 1988 and the Crella incrustans extracts on 9 to 14 November 1989. Extracts (5) and (6) were also tested at $0.1 \times$ the above concentrations, and the cholesterol (Extract 12) at 0.1 and 0.01 dilutions. Cholesterol (Aldrich) was used as supplied. The reason for including cholesterol was that, in the 1988 trials with Mycale sp. extract, all 3 fractions were repellent (see 'Results'). A possible reason for repulsion was that we were observing a non-specific response to the physical nature of the ether extract rather than one mediated by the unique chemical structure of an active compound(s). Cholesterol is a significant component of many sponges (Goad 1979) and was chosen because it seemed that it would ade- 
quately mimic the physical characteristics of the ethersoluble extract of Mycale sp.

Responses of larvae to sponge extracts. The responses of larvae to extracts were tested by giving a single larva a binary choice: filter paper soaked in extract or an equal area of paper soaked in solvent only. This was done beneath the Edithburgh pier where larvae were obtained by fixing larval traps over adult colonies (Davis 1987), by gently shaking reproductive colonies to dislodge brooded larvae or by catching newly released larvae in mid-water with a large syringe (20 $\mathrm{ml}$, with the nozzle enlarged). Each trial was done in a $70 \mathrm{ml}$ screw-top plastic container with 1 larva per container. In the laboratory, discs of filter paper (Whatman \# 1) of the same diameter $(45 \mathrm{~mm})$ as the container lids were folded to mark the mid-line, and then extract was carefully pipetted onto one half first, followed by control solvent onto the other half. This order had the effect, if there was an error at the boundary, of spreading solvent onto the extract side rather than extract onto the solvent side. This was merely a precautionary technique; in fact the pipetting could be done quite accurately. The disc was allowed to dry and then placed into the lid, which was screwed on. Containers were transported to the pier thus, containing dry treated papers in air. Underwater, the container was opened to allow seawater to enter, then a single larva was released into it, and the lid replaced so that the paper was gripped under the lid even when the container was upright. Containers were placed lidupwards in a weighted rack on the seafloor, direction of the control and extract sides of the papers being varied haphazardly. Larvae invariably swam upwards in these containers; thus, although about one third of them settled on the plastic sides of the container, most settled on the paper. Many larvae settled within seconds; a minority swam for an hour or more and finally settled. Racks were left on the seafloor for times varying from 1.5 to $3 \mathrm{~h}$ and then scored. Only larvae settling on paper were scored, and the model for analysis was that if the extract had no influence, half would be expected

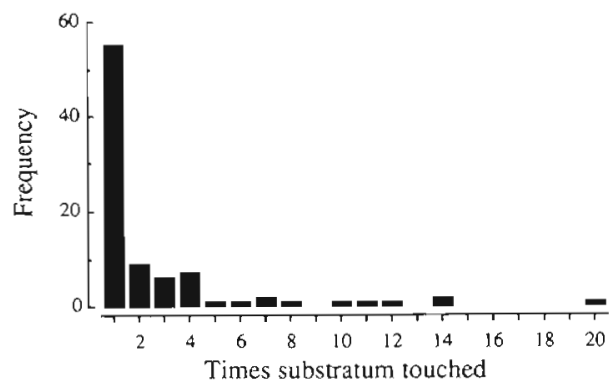

Fig. 1. Podoclavella moluccensis. Number of contacts made by larvae $(n=89)$ with substrata, prior to settlement. All observations made using SCUBA beneath Edithburgh pier, South Australia to settle on the extract side and half on the control side of the paper; this was tested using log-likelihood ratio (G) tests for goodness-of-fit (Sokal \& Rohlf 1981).

Antibacterial activity. Ether extracts of both sponge species were tested for their ability to inhibit growth of bacteria. In the laboratory a standard disc bioassay (White et al. 1986) was used to test the following bacteria. Gram-positive: Bacillus subtilus and Staphylococcus epidermis; Gram-negative: Escherichia coli, Pseudomonas aeruginosa and Serratia morcescens.

\section{RESULTS}

\section{In situ observations of settlement}

Most larvae $(63 \%, \mathrm{n}=89)$ settled on their first encounter with a substratum, but $6.7 \%$ made 10 or more contacts prior to settlement (Fig. 1).

The number of initial contacts differed significantly from that expected (Fig. 2). The data-set was not homogeneous $\left(G_{6}=28.25, \mathrm{p}<0.001\right)$ and a simultaneous test procedure (Sokal \& Rohlf 1981) identified homogeneous groups (groups joined by lines were not significantly different at the $5 \%$ level of significance), as shown in Table 1

Crella incrustans and Tedania sp. B received less than one seventh of the contacts expected, fewer contacts than for any other category of substratum. Furthermore, when repeated contacts (i.e. total contacts) are considered, C. incrustans and Tedania sp. B received $<1 \%$ of all contacts despite accounting for almost $14 \%$ of the available area.

\section{Responses of larvae to extracts}

Mycale sp. Trials were run over 3 d. Data pooled across these $3 \mathrm{~d}$ revealed that the crude extract and each of the fractions were avoided by settling larvae, relative to solvent-treated filter paper, and that they did

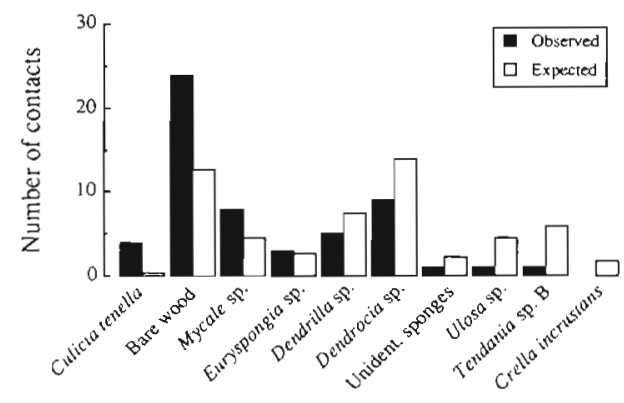

Fig. 2. Observed and expected number of initial contacts by Podoclavella moluccensis larvae on 12 substrata beneath Edithburgh pier, South Australia 
Table 1. Podoclavella moluccensis. Settlement of larvae on various substrata. Homogeneous groups of substrata were identified using a simultaneous test procedure (Sokal \& Rohlf 1981). Groups joined by lines were not significantly different at the $5 \%$ significance level

\begin{tabular}{|lllll}
\hline Bare wood Mycale sp. & $\begin{array}{l}\text { Euryspongia sp., Dendrilla sp. } \\
\text { Culicia tenella } \\
\text { and unidentified } \\
\text { sponges }\end{array}$ \\
\hline
\end{tabular}

not differ significantly from each other (Table 2). To check for heterogeneity in larval behaviour between days their settlement on crude ether extract was examined each day (Table 3). Significant heterogeneity between days and an analysis of subtables showed that relatively more larvae settled on the crude extract on Day 2. Fractions 2-99A and 299-C were tested on Day 2 ; the proportion settling on them is not significantly higher than for other extracts and so whatever the day effect' was, it does not appear to have affected our conclusion. Davis (1989) has suggested that daily release of Podoclavella moluccensis larvae is correlated with water temperature. We did find differences between days in the number of larvae obtainable for tests, but there was no evidence that this influenced the results of the trials.

Table 2. Settlement of Podoclavella moluccensis larvae on filter papers treated with ether extract of Mycale sp. and 3 fractions, vs papers treated with solvent only. For heterogeneity $G_{3}=1609$, non-significant; for fit of totals to $1: 1$ ratio $G_{1}=44.27, \mathrm{p}<0.001$

\begin{tabular}{|lcc|}
\hline Extract & $\begin{array}{c}\text { Settled on } \\
\text { control }\end{array}$ & $\begin{array}{c}\text { Settled on } \\
\text { extract }\end{array}$ \\
\hline Crude (ether) & 38 & 11 \\
$2-99 A$ & 16 & 4 \\
$2-99 B$ & 18 & 2 \\
$2-99 C$ & 16 & 4 \\
Total & 88 & 21 \\
\hline
\end{tabular}

Table 3. Settlement of Podoclavella moluccensis larvae on filter papers treated with ether extract of Mycale sp. vs papers treated with solvent only (control), on 3 consecutive days, November 1988. $G_{2}$ for heterogeneity between rows $=9.42$, $p<0.01$

\begin{tabular}{|ccc|}
\hline Day & $\begin{array}{c}\text { Settled on } \\
\text { control }\end{array}$ & $\begin{array}{c}\text { Settled on } \\
\text { extract }\end{array}$ \\
\hline 1 & 14 & 3 \\
2 & 12 & 8 \\
3 & 12 & 0 \\
\hline
\end{tabular}

Crella incrustans. In the 1989 trials on extracts of Crella incrustans, up to 5 different extracts were tested simultaneously on a given day, and certain extracts (or cholesterol) were run on successive days to check for heterogeneity in larval responses between days. There was never significant heterogeneity between runs on a given extract, and so the pooled results for each extract are given in Table 4 .

Extracts 2-181A and B were significantly avoided, and did not differ significantly from one another (Table 4. $G_{1}$ for heterogeneity $=1.07$, non-significant). Results from the trials with cholesterol were compared with these extracts and did not differ significantly from them $\left(G_{2}\right.$ for heterogeneity $=1.24$, non-significant $)$. When diluted to $1: 10$ or further, the extracts and cholesterol no longer showed detectable deterrence by this test (Table 4).

The set of fractions from the ether extract, 2-180Q, P, $\mathrm{M}, \mathrm{L}$ and 2-183A, were heterogeneous (Table $5 ; G_{4}=$ 17.5, $p<0.005$ ) but the Sephadex fractions, $2-181 \mathrm{Q}, \mathrm{P}$, $M$ and $L$, were homogeneous $\left(G_{3}=5.07\right.$, non-significant) and their pooled totals (94 control; 57 extract) were significantly different from a $1: 1$ ratio $\left(G_{1}=9.16\right.$, $\mathrm{p}<0.005)$. The entire table was heterogeneous because $2-183 \mathrm{~A}$ was significantly preferred over the control.

In summary, the butanol extract and the more polar fractions of the ether extract were repellent, and did not differ significantly from one another; the most nonpolar fraction of the ether extract was attractive to settling larvae and was significantly different from all the rest.

Antibacterial activity. Non antibacterial activity was observed for either extracts of either sponge species; zones of inhibition were not apparent.

\section{DISCUSSION}

\section{Field observations of settlement}

A high proportion of larvae settled on their first encounter with a substratum, even though highly preferred substrata (such as bare wood; Fig. 2) accounted 
Table 4. Settlement of Podoclavella moluccensis larvae on filter papers treated with crude extracts of Crella incrustans or cholesterol at 0.1 or 0.01 dilutions vs papers treated with solvent only (control), in November 1989. NS: not significant

\begin{tabular}{|lcccc|}
\hline Extract & $\begin{array}{c}\text { Settled on } \\
\text { control }\end{array}$ & $\begin{array}{c}\text { Settled on } \\
\text { extract }\end{array}$ & G $_{1}$ for fit to 1:1 & Significance \\
\hline Ether extract 2-181A & 26 & 11 & 6.26 & $\mathrm{p}<0.025$ \\
$0.1 \times 2-181 \mathrm{~A}$ & 6 & 11 & 1.49 & $\mathrm{NS}$ \\
Butanol extract 2-181B & 22 & 5 & 11.56 & $\mathrm{p}<0.001$ \\
$0.1 \times 2-181 \mathrm{~B}$ & 7 & 4 & 0.83 & $\mathrm{NS}$ \\
Cholesterol & 12 & 3 & 5.78 & $\mathrm{p}$ \\
$0.1 \times$ cholesterol & 7 & 3 & 0.025 & $\mathrm{NS}$ \\
$0.01 \times$ cholesterol & 7 & 5 & 0.34 & $\mathrm{NS}$ \\
\hline
\end{tabular}

Table 5. Settlement of Podoclavella moluccensis larvae on filter papers treated with 4 Sephadex fractions (2-181Q, P, M and L) and the least polar vacuum chromatography fraction (2-183A) of ether extract 2-181A of Crella incrustans. NS: not significant; $G_{4}$ for heterogeneity between rows $=17.5, \mathrm{p}<0.005$

\begin{tabular}{|lcccc|}
\hline Extract & $\begin{array}{c}\text { Settled on } \\
\text { control }\end{array}$ & $\begin{array}{c}\text { Settled on } \\
\text { extract }\end{array}$ & $G_{1}$ for fit to 1:1 & Significance \\
\hline $2-181 \mathrm{Q}$ (most polar) & 16 & 3 & 9.77 & $\mathrm{p}<0.005$ \\
$2-181 \mathrm{P}$ & 43 & 29 & 2.74 & NS \\
$1-181 \mathrm{M}$ & 15 & 10 & 1.01 & NS \\
$1-181 \mathrm{~L}$ & 20 & 15 & 0.72 & NS \\
$2-183 \mathrm{~A}$ (least polar) & 5 & 17 & 6.92 & $\mathrm{p}<0.01$ \\
\hline
\end{tabular}

for less than $15 \%$ of the area available for settlement. Larvae of a tropical ascidian also made a high proportion of initial contacts with highly preferred substrata (D. Stoner pers. comm.).

It is noteworthy that Mycale sp. was contacted by larvae more frequently than expected (Fig. 2). Yet this sponge was not a preferred site for actual settlement (Davis 1987). These data indicate that deterrence occurs on contact, not at a distance. In contrast, contact with Crella incrustans was so rare that it is worth considering the hypothesis that it releases waterborne chemicals that act prior to contact. The release of such substances has been demonstrated in laboratory trials and near in situ conditions, although their effects in the field remain unclear (Young \& Chia 1981, Thomson 1985, Walker et al. 1985).

\section{Responses of larvae to extracts}

Ether-extractable compounds inhibited larval settlement and may therefore account for the observed rejection of the sponge Mycale sp. Many epibenthic taxa, especially colonial species, possess secondary metabolites which presumably function to deter epibionts, endobionts and predators (Dyrynda 1986, Davis et al. 1989, Wahl 1989).
Over the past $5 \mathrm{yr}$, sponges of the genus Mycale have been reported as possessing a number of secondary metabolites. Most are polar lipophilic compounds with a variety of chemical structures: nucleosides (Kato et al. 1985), macrolides (Fusetani et al. 1989), terpenes (Capon \& MacLeod 1985, 1987, Corriero et al. 1989) and compounds of amino acid/acetogenin origin (Perry et al. 1988, 1990, Fusetani et al. 1989). They have been shown to have antifungal, antiviral, antitumor and antimicrobial activity (Capon \& MacLeod 1985, Perry et al. 1988, 1990, Fusetani et al. 1989). In addition, some inhibit cell division of fertilized starfish eggs (Kato et al. 1985, Fusetani et al. 1989).

In preliminary trials with Mycale sp., we found some indication that the antifouling activity lay amongst the polar lipophilic compounds but this has not been easy to confirm. Results of the trials with cholesterol indicate that a range of steroid compounds may also influence settlement preferences. This may explain the fact that we observed activity in all fractions of the Mycale sp. extract (Table 2). The lipophilic metabolites from this species of Mycale are mainly facts, lipids and steroids (van Altena unpubl.). This suggests that, in this type of study, care should be taken when ascribing a specific biological activity to a particular fraction.

We found no convincing evidence that allelochemicals from Crella incrustans act at a distance. During our 
trials larvae often settled on the plastic or on control paper in very close proximity to the filter paper coated with extract. It was also observed (Davis \& Butler unpubl.) that larvae of Podoclavella moluscensis settled (on wood) very close to or touching colonies of $C$. incrustans and survived for at least a month. Nevertheless it is possible that water-borne components of the extract of $C$. incrustans may act to delay the metamorphosis of larvae, as Young \& Chia (1981) demonstrated for a didemnid ascidian.

It does appear, however, that some component of the extracts deters settlement on contact and that, in the case of Crella incrustans, the activity resides amongst the polar lipophilic components. The most non-polar fraction appeared to be significantly attractive, and there was a suggestion that the strongest repellant activity was at the polar end of the remainder. In contrast to Mycale sp., very few if any secondary metabolites have been reported from the genus Crella. This work is continuing and it should be possible to use the bioassay to isolate a pure active compound (or compounds) from C. incrustans.

It is interesting that the non-polar fraction of Crella incrustans was apparently attractive. This material is essentially similar to the major components present in Ulosa sp. (van Altena unpubl.), a sponge which appears to have less inhibitory effect on the larvae (Davis 1987). This type of 'essential oil' appears to be present in many sponges, especially the highly coloured ones. It is plausible that these attractive substances are present as a result of basic biochemical processes and that selection from fouling has led to the evolution of other, secondary compounds that mask their attractive effect and deter larval settlement. This could explain the presence of both attractive and deterrent compounds in the same species.

The toxicity of secondary metabolites is a potentially potent selective force in moulding the settlement preferences of larvae, and in the Porifera the degree of microfouling has been negatively correlated with the toxicity of metabolites (McCaffrey \& Endean 1985, Thompson et al. 1985). There was, however, no evidence that the inhibition of settlement on Mycale sp. or Crella incrustans was mediated by toxicity. Deaths of ascidian larvae in the test containers were few and unrelated to the extract under test.

In determining the appropriate concentrations of extracts we assumed that metabolites were concentrated at the surface of both sponge species. Yet 1:10 dilutions of the inhibitory extracts did not prove effective against settling larvae. If our assumption is not justified then these data would suggest that secondary metabolites may not be the only inhibitors of settlement in these sponges. The settlement of larvae on the surface of an organism may be inhibited physically or chemically - by various skeletal structures, mucus, production of secondary substances, or by a combination of these defences (Davis et al. 1989, Wahl 1989). In addition, invertebrate larvae frequently show preferences for surfaces possessing a microbial film (Davis et al. 1989). We failed to detect any antibacterial activity in ether extracts of either sponge species and hence found no evidence to suggest the inhibition of film formation.

The role of steroids (noting the effect of cholesterol in our trials) is unclear. Many sponges either produce steriods or aquire them from symbiotic micro-organisms (Goad 1979). These steroids could have many functions (e.g. structural), although a defensive function is possible. The effective concentrations of cholesterol (in comparison with the effective concentrations of ether extract) suggest that the concentrations, at least in Mycale sp., are high enough to have an inhibitory effect. The validity of this suggestion remains to be tested.

Acknowledgements. For assistance in the field we thank A. T. D. Bennett, J. M. Davis, I. Magraith, G. A. Powell and M. Robinson. The antibacterial assays were done by $D$. Tscharke and $V$ Vingelis. We are grateful to $J$. Hooper for the identification of sponge specimens. D. J. Ayre and R. J. Whelan made helpful comments on the manuscript. A.R.D. was financially supported by the Ecological Society of Australia, the Victorian Institute of Marine Science and a University of Adelaide Postgraduate Research Award, A.J.B. and I.V.A. by an Adelaide University Research Grant. This a joint contribution from the Coobowie Marine Research Station and the Ecology and Genetics Group (contribution number 80 ) at the University of Wollongong.

\section{LITERATURE CITED}

Burke, R. D. (1983). The induction of metamorphosis of marine invertebrate larvae: stimulus and response. Can. J. Zool. 61: 1701-1719

Capon, R. J., MacLeod, J. K. (1985). Structural and stereochemical studies on marine norterpene cyclic peroxides. Tetrahedron $41 \quad 3391-3404$

Capon, R. J., MacLeod, J. K. (1987). Structural and stereochemical studies on marine norterpene cyclic peroxides. Part 2. J. nat. Products 50: 225-229

Coll, J. C., Bowden, B. F. (1986). The application of vacuum liquid chromatography to the separation of terpene mixture. J. nat. Products 49: 934-936

Connell, J. H. (1961). Effects of competition, predation by Thais lapillus, and other factors on natural populations of the barnacle Balanus balanoides. Ecol. Monogr. 31. 61-104

Connell, J. H. (1985). The consequences of variation in initial settlement vs. post-settlement mortality in rocky intertidal communities. J. exp. mar. Biol. Ecol. 93: 11-45

Corriero, G., Madio, A., Mayol, L., Piccialli, V., Sica, D. (1989) Rotalin $\mathrm{A}$ and $\mathrm{B}$, two novel diterpene metabolites from the encrusting Mediterranean sponge Mycale rotalis (Bowerbank). Tetrahedron 45: 277-288

Davis, A. R. (1987). Variation in recruitment of the subtidal 
colonial ascidian Podoclavella cylindrica (Quoy and Gaimard): the role of substratum choice and early survival. J. exp. mar. Biol. Ecol. 106: 57-71

Davis, A. R. (1988). Effects of variation in initial settlement on distribution and abundance of Podoclavella moluccensis Sluiter J. exp. mar. Biol. Ecol. 117: 157-167

Davis, A. R. (1989). Daily larval release and settlement correlate with temperature in a temperate Australian ascidian In: Ryland, J. S., Tyler, P. A (eds.) Reproduction, genetics and distribution of marine organisms. 23rd European Marine Biology Symposium. Olsen \& Olsen, Fredensborg, Denmark, p. 61-65

Davis, A. R., Butler, A. J. (1989). Direct observations of larval dispersal in the colonial ascidian Podoclavella moluccensis Sluiter: evidence for closed populations. J. exp. mar Biol. Ecol. 127: 189-203

Davis, A. R., Targett, N. M., McConnell, O. J., Young, C. M. (1989). Epibiosis of marine algae and benthic invertebrates: natural products chemistry and other mechanisms inhibiting settlement and overgrowth. In: Scheuer, P. J. (ed.) Bioorganic marine chemistry, Vol. III. Springer-Verlag, Berlin, p. 85-114

Dyrynda, P. E. J. (1986). Defensive strategies of modular organisms. Phil. Trans. R. Soc. (Ser. B) 313: 227-243

Fusetani, N., Yasumoro, K., Matsunaga, S., Hashimoto, K. (1989). Mycalolides A-C, hybrid macrolides of Ulapualides and Halichondramide, from a sponge of the genus Mycale. Tetrahedron Lett. 30: 2809-2812

Gaines, S., Roughgarden, J. (1985). Larval settlement rate: a leading determinant of structure in an ecological community of the marine intertidal zone. Proc. natn. Acad. Sci. U.S.A. $82: 3707-3711$

Goad, L. J. (1979). Sterols of marine invertebrates: composition, biosynthesis and metabolites. In: Scheuer, P. J. (ed.) Marine natural products: chemical and biological perspectives, Vol. II. Academic Press, New York, p. 76-173

Grosberg, R. K. (1981). Competitive ability influences habitat choice in marine invertebrates. Nature, London 290: $700-702$

Kato, Y., Fusetani, N., Matsunaga, S, Hashimoto, K. (1985) Bioactive marine metabolites IX. Mycalisínes A \& B, nove] nucleosides which inhibit cell division of fertilized starfish eggs, from the marine sponge Mycale sp. Tetrahedron Lett. 26 : $3483-3486$

This article was presented by A. J. Underwood, Sydney, Australia
Kay, A. M. Butler, A. J. (1983). 'Stability' of the fouling communities on the pilings of two piers in Southern Australia. Oecologia 56: 58-66

Kay, A. M., Keough, M. J. (1981). Occupation of patches in the epifaunal communities on pier pilings and the bivalve Pinna bicolor at Edintburgh, South Australia. Oecologia 48: $123-130$

Keough, M. J., Downes, B. J. (1982). Recruitment of marine invertebrates: the role of active larval choice and early mortality. Oecologia 54: 348-352

McCaffrey, E. J., Endean, R. (1985). Antimicrobial activity of tropical and subtropical sponges. Mar. Biol. 89: 1-8

Perry, N. B., Blunt, J. W., Munro, M. H. G., Pannell, L. K. (1988). Mycalamide A, an antiviral compound from a New Zealand sponge of the genus Mycale. J. Am. chem. Soc. 110: $4850-4851$

Perry, N. B., Blunt, J. W., Munro, M. H. G., Thompson, A. M. (1990). Antiviral and antitumour agents from a New Zealand sponge, Mycale sp. II. Structures and solution conformations of mycalamides $\mathrm{A}$ and B. J. org. Chem. 55: $223-227$

Sokal, R. R., Rohlf, F. J. (1981). Biometry, 2nd edn. W. H. Freeman \& Company, San Francisco

Thompson, J. E. (1985). Exudation of biologically-active metabolites in the sponge Aplysina fistularis I. Biological evidence. Mar. Biol. 88: 23-26

Thompson, J. E., Walker, R. P., Faulkner, D. J. (1985). Screening and bioassays for biologically-active substances from forty marine sponge species from San Diego, California, U.S.A. Mar. Biol. 88: 11-21

Wahl, M. (1989). Marine epibiosis. I. Fouling and antifouling some basic aspects. Mar. Ecol. Prog. Ser. 58: 175-189

Walker, R. P., Thompson, J. E., Faulkner, D. J. (1985). Exudation of biologically-active metabolites in the sponge Aplysina fistularis. II. Chemical evidence. Mar. Biol. 88: 27-32

White, R. J., Maiese, W. M., Greenstein, M. (1986). Screening for new products from microorganisms. In: Demain, A. L., Solomon, N. A. (eds.) Manual of industrial microbiology. Chapter 2. American Society for Microbiology, Washington, D.C., p. 24-31

Young, C. M., Chia, F. S. (1981). Laboratory evidence for delay of larval settlement in response to a dominant competitor Int. J. Invert. Reprod. Dev. 3: 221-226

Manuscript first received: December 12, 1990

Revised version accepted: March 5, 1991 